\title{
Analyzing the Process of Using Project-Based Learning Method in Teaching the Concept of Tens-Ones in Elementary Math Course
}

\author{
Zeynep Doğan $^{1, *}$, Beyza Karabulut ${ }^{2}$ \\ ${ }^{1}$ Department of Basic Education, Faculty of Education, Yildiz Technical University, Turkey \\ ${ }^{2}$ Department of Primary Education, Yildiz Technical University, Turkey
}

Copyright $@ 2019$ by authors, all rights reserved. Authors agree that this article remains permanently open access under the terms of the Creative Commons Attribution License 4.0 International License

\begin{abstract}
The aim of this study was to examine the process of applying the project-based teaching method in teaching tens and ones concept to the $1^{\text {st }}$ grade students with an academic perspective and to determine the views of the students about this process. The research design was determined as a case study. For collection data, observation and interview techniques from qualitative research techniques were used. The sample of the study consisted of 37 students attending the first grade of primary school in a public school. The process of teaching tens and ones concept which was one of the themes in Math course with the students in the research sample was supported with project-based teaching method. The implementation was carried out in a 4-week period. As a data collection tool, observation form and semi-structured interview form were used. According to the results obtained from the research, students generally had a positive view about the method applied. It was also observed that the process contributed to the students' learning of the subject. Besides, all the students stated that they had a positive affective process regarding the implementation period. Since the process also involved a group work, it was observed that some students had difficulties in working with their friends in this process. It was seen that the students need the teacher guidance in the process of structuring the projects at the most.
\end{abstract}

Keywords Mathematics Education, Primary School Students, Project-Based Learning, Tens-Ones

\section{Introduction}

Mathematics is the common name of the sciences that examine the properties of quantities based on number and measure basis, such as arithmetic, algebra, geometry [1].
Education is very crucial in societies that care about knowledge. In the development of a country, in the formation of an information society, mathematics teaching is also important for the welfare of the country. Teaching Mathematics enables a person to improve his thoughts and gain a different perspective [2]. Teaching Mathematics gives a place to the problem-solving skill in its center. It is seen that this approach has recently caused Mathematics educators give importance to the issue and reconstruct the teaching Mathematics programs of after 1980s [3]. The teaching materials used to make teaching mathematics fun and make students love mathematics must be diversified. Thus, the students will be at the center of the process, math will become more fun and will be loved [4]. In addition, teaching mathematics should give students the opportunity to understand that mathematics is part of their lives and should support the feeling that Math is worth to effort. This situation, especially during primary school, requires that the experience of Mathematics must be taken from simple to difficult, from concrete to abstract [5].

The judgement that teaching mathematics is only the achievement of determined goals and behaviors is an approach that prevents students from using mathematical knowledge in their daily lives. Because, apart from the specific objectives of the course and the subjects that provide access to the desired goals, there are also general objectives of teaching mathematics such as providing problem solving skills to students [6]. According to Cakmak [7], there are many elements for teaching Mathematics to be effective, but the most important role is the role of teachers. Teachers who use mathematical and pedagogical knowledge by synthesizing them are particularly important in the acquisition of mathematical knowledge and skills in elementary school students. The students' efforts to do mathematical studies and sympathize with mathematics from the beginning depend on how they think about it in a positive way. To gain these 
behaviors, teaching mathematics courses offered at primary school period are very important [8].

According to MEB [9], the learning-teaching process should start with concrete experiences. Elementary school students learn more meaningfully in learning environments where information is expressed in concrete terms. Therefore, it is very important to use concrete expressions and modeling in teaching mathematics. According to Korkmaz and Kaptan [10], the experience and the learning activities of the individuals have changed with the significant changes and developments in technology recently. The individual is in a position in the life to change the information through his/her creativity and use it. According to this change, education must leave its place to the model of the individual who reaches knowledge and can solve his/her problems by using the information he/she reaches. Today's educational scientists think that students should be able to look critically at events during and after their learning life, exchange information with their peers, and construct the information in environments where the teacher is only a guide [11]. One of the teaching methods that can be used in this direction is project-based learning which blends traditional subject-matter goals and objectives with authentic learning environments [36].

The project means designing, developing the project, imagining it, planning it, and in this sense, it refers to seeing a job mentally that is intended to be done before planning phase [12]. According to Guven [13], project activities should be considered to enable students to become individuals who are able to solve problems in our schools. The projects enable students to conduct scientific research and acquire in-depth knowledge about a subject. Also, project studies develop the abilities and the aesthetic skills of the students. In this aspect, projects have the potential to help people learn [35]. In project-based learning, teachers need to know the students' level of understanding and what they have learned in the project process. Alternative assessment methods such as student presentations, evaluating interviews with students during the project process, and portfolio assessment should be used rather than traditional measurement methods [14].

According to Saracoglu, Akamca and Yesildere [15], students should prepare their project presentations carefully by planning. In addition to the preparation of the project, the presentation phase is also important. It will provide motivation for students to share the projects that they have prepared in a long time with their environment. Besides, students' ability to make presentations and to speak in front of the community will also develop. According to Korkmaz and Kaptan [16], the project-based learning approach is a process that develops the knowledge and skills of individuals, supports lifelong learning, and encourages individuals to learn in a self-controlled manner. According to Cengizhan [17], project-based teaching is a suitable method for students who learn by working with a group or friends, in other words, in a cooperative environment. Presenting the products produced during the project-based teaching program increases the efficiency of learning to use and share the knowledge and skills acquired by the individuals in the group [18]. Bell explains project-based learning as an innovative learning approach that teaches many strategies critical to success in the twenty-first century [34]. This approach is designed to engage students in investigation of authentic problems [35]. It is also a student-driven and teacher facilitated approach [34].

Angin [19] examined the effect of project-based education program on the development of size/comparison and quantity concept of children aged 60-71 months. Considering the studies conducted about the subject, it is observed that there are studies examining the effects of project-based teaching on student success ([20]; [21]; [22]), attitudes ([23], [22]), different cultures and perspectives [24]. This research focuses on the implication of the project-based teaching method as well as the normal course process and the effect of this process on the students' situations in learning environment and their learning. It is expected to open a new window into the existing studies due to the facts that this study was carried out in relation to the concepts of tens and ones which had not been discussed in previous studies and that it was conducted with the first graders who were new in their study life. The aim of the study is to use the project-based teaching method in the process of teaching the concepts of tens and ones, which is one of the first-grade concepts of primary school mathematics course, and to determine the observation results and the student views about this teaching process. The problem statement of the research was determined as "What is the use project-based teaching method in the process of teaching tens and ones concepts which is one of the themes of first graders in elementary school math course, the observation results and students' views related to the teaching process?”.

\section{Method}

\subsection{Research Design}

A case study design of qualitative research methods is used in the research. Case study is a research method that works on a current phenomenon within the framework of real life, used in cases where the boundaries between the phenomenon and its content are not clear and has multiple evidences [25]. In the process of obtaining data, observation and interview techniques from qualitative research techniques were used. In this study, the design of the study was determined as case study due to the observation and evaluation of student opinions regarding a teaching process carried out by project-based teaching method. 


\subsection{Sampling}

The sample of the study consisted of 37 students studying in the first grade in a primary school in Istanbul in 2018-2019 academic year. 19 of the students were girls and 18 of them were boys. The age of the students ranged from 5,5 to 7 years.

\subsection{The Implication of Project-Based Teaching Method}

First, the students were informed about what project work was and how it was done. It was informed that a 4-week process would be passed, the teachers would be interviewed every week, the projects would be evaluated, and if there were missing or incorrect directions, appropriate guidance would be provided. It was stated that the projects should be completed at the end of this 4-week period. Since there were 37 people in the class, project groups were formed with a total of 9 groups including 8 groups with 4 people and 1 Group with 5 people. Attention was given to create heterogeneous groups in themselves and intergroup homogeneity within each group. After the groups were formed, changes were made in a way that would not disturb the group order among those who wanted to work together based on the request of the students. After that, project topics were given to each group. Project topics were determined as 3 educational games, 4 educational materials and 2 drama studies. The contents of the project were created within the framework of the acquisition of first grade tens and ones sub-learning areas. This acquisition was as follows; 'Shows a group of objects between 10 and 20 (including 10 and 20) by dividing into tens and ones, writes and reads the numbers corresponding to these objects [26]. Table 1 shows the distribution of project topics by groups.

Table 1. Student group and project information in the project-based teaching process

\begin{tabular}{ccc}
\hline Grup No & $\begin{array}{c}\text { Number of Students } \\
\text { in the Group }\end{array}$ & Projects \\
\hline 1 & 4 & Educational Games \\
\hline 2 & 4 & Educational Games \\
\hline 3 & 4 & Educational Games \\
\hline 4 & 4 & An Educational Material \\
\hline 5 & 4 & An Educational Material \\
\hline 6 & 4 & An Educational Material \\
\hline 7 & 4 & An Educational Material \\
\hline 8 & 4 & Educational Drama \\
\hline 9 & 5 & Educational Drama \\
\hline
\end{tabular}

In the project number 1 mentioned in Table 1 , the educational game was designed. The students painted 2 separate large-size plastic bottles as they wanted and wrote tens on one of the bottles and ones on the other one. They put some pompon balls in a box. One of the students said a number from 1 to 20 and asked his friend to throw the pompon ball in the box labelled as tens based on the amount of that how many tens there were in the number mentioned and throw pompon balls in the box labelled as ones regarding the amount of that how many ones there were in the number mentioned. The visual of this game was shown in Figure 1.

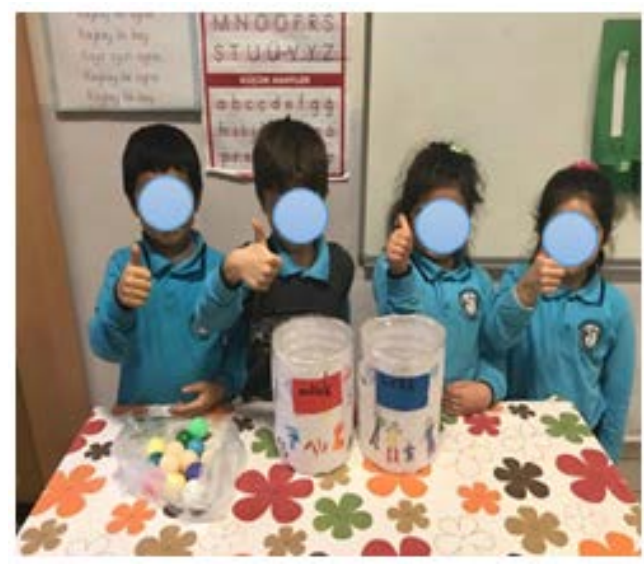

Figure 1. Educational Game

In the educational game developed in Project 2, students put their colorful tens and ones cards they prepared before on a large sheet. They chose a friend among them, and that student stepped on the colorful number cards by using his hands and feet based on how many tens and ones there were in the number pronounced by the members of Project 2. The visual of this game was shown in Figure 2.

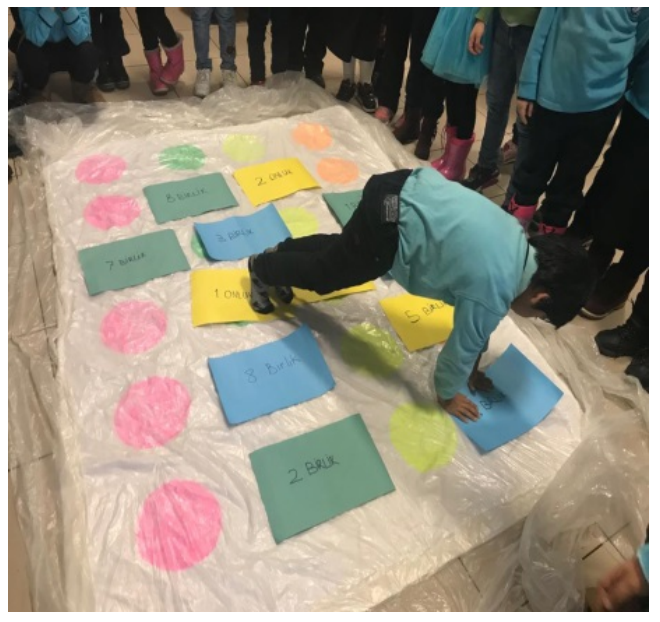

Figure 2. Educational Games

In the project 3 , another educational game was developed. Students designed rings in this project. One of the rings was considered as tens whereas the other ring was thought as ones. The students who were volunteers tried to throw the rings at the 2 bars fixed to the platform regarding the number of tens and ones in the number mentioned by the classmates. When the rings were off target, they had the right to throw until the numbers of tens and ones were obtained. The visual of this game was shown in Figure 3. 


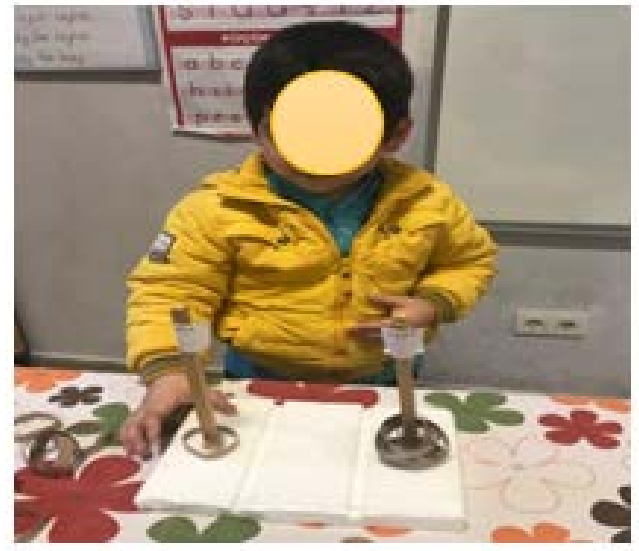

Figure 3. Educational Game

An educational material was designed in the Project 4. The students put the two circles, which were cut out of cardboard, into the rectangular arrangement they had prepared. On the first circle, 1 and 2 which symbolized tens and on the second circle the numbers from 0 to 9 that stated ones were written. Two windows were opened on the front side of the rectangle, above each circle. Thus, the shape formed was in the form of a wheel. After verbally expressing the number of tens and ones in the number stated, the student showed the specified number by rotating the wheels.

In Project 5, an educational material was designed. Students placed 2 bars in a plastic bowl by drilling holes from the two points of the upper surface. They also put ring-shaped pasta in a bowl. They put the number cards from 1 to 20 in a box. They chose a number card from the box with eye closed and checked the number card. They put pasta on the bars regarding the number of tens and ones in the number card that was chosen.

In the educational material designed in Project 6, students cut and pasted 2 rectangular strips from top to bottom onto a carton. They wrote tens under one of the stripes and ones under the other stripe. They put sticky stars prepared from cardboard before in a box. They took a number by asking their classmates who wanted to talk and stuck the stars regarding the number of tens and ones in the number stated.

In the educational material 7, the students fixed 9 stick shaped pasta on for each of two surfaces prepared from plastic sponge. They called stick shaped pasta as tens and ones spaghettis. They pulled up the number of pastas regarding the number of tens and ones in the number stated by their classmates and put them on a platform separately. Then, they explained the number of tens and ones in the number.

In the project 8, educational drama was carried out. The students dramatized a story including the concept of tens and ones by using the puppets of lion and birds they prepared. The story was created by the students. They told the concept of tens and ones by making a story it visually and aurally. The visual figure for this drama was shown in
Figure 4.

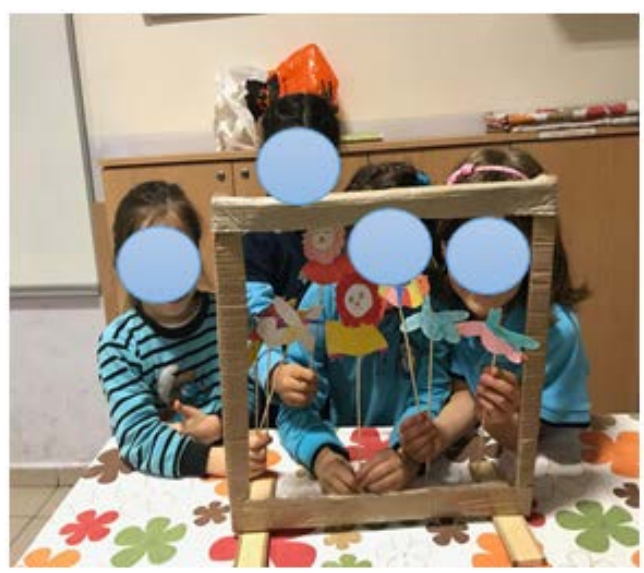

Figure 4. Educational Drama

In the educational drama carried out in the Project 9, students narrated the numbers in a story they created by using stick puppets made from colorful cardboards.

The progress of the students about their projects was regularly monitored by the researcher every week. During the follow-up process, the students were directed in a proper way and their questions were answered. Some of the students had a very low level of readiness and some of them were very young. Therefore, these were taken into consideration during the guidance process. The researcher was responsible for guiding the students in the process.

\subsection{Data Collection Tools}

In the study, observation and interview forms were used as data collection tools.

\subsubsection{Observation Form}

The observation form was filled with each group for each week according to the following subheadings.

- What is the level of students' readiness? (It was evaluated during the first week)

- What was discussed with the students about the project today?

- What questions did the groups ask to the researcher to consult about the project?

- What ideas did the researcher give to the students to support them?

- What is the applicability level of the study in the classroom? (Evaluation of the whole process)

\subsubsection{Interview Form:}

At the end of 4 weeks with project-based teaching method, semi-structured interviews were conducted with the students to determine their views on this process. An interview form was created by the researcher for these interviews. The questions given below were included in the interview form. 
1. How did you feel when you implemented the project in this process?

2. When you work in the group, what kind of contributions do you think you have to the group?

3. What benefits did your project have for you to understand and reinforce the subject?

4. Have you experienced anything that adversely affected you in this process? Can you tell if you've met?

5. What were the benefits of your work in terms of communication with friends?

\subsection{Data Collection and Analysis}

The data obtained in this study were collected in two ways: Observation and Semi-structured interviews.

Observations were carried out during the implementation process. Observation forms were filled out each week for each group separately. The semi-structured interviews were conducted with the students at the end of the implementation period. The interviews were provided with 15 students. Since the students were in the first grade of the primary school, the necessary explanations were made in detail at the beginning of the study. The interview forms applied to the participants were given from 1 to 15 to facilitate the analysis of the findings. The answers given by the students to the questions were recorded in the interview forms by the researcher.

Descriptive analysis approach was used to analyze the collected data. The reason for the descriptive analysis is to organize and interpret the obtained findings and present them to the reader in a coherent sense. The data obtained for this purpose were described in a logical manner and then interpreted.

\section{Findings}

\subsection{Observation Findings}

It was observed that most of the students had a low level of readiness regarding the readiness of the students as the first item in the observation form. Because many students in the process had difficulty especially in cutting the materials such as cardboard and paper. It was observed that fine motor skills of the students did not develop sufficiently. It was seen that the students did not perform enough activities to develop their small muscles before the school. Besides, it was observed that many students were lack the sense of responsibility. When some students were assigned a task, it was seen that the student did not perform the task when the process was not followed regularly. In addition, some students had difficulty in adapting to group work.

Considering the observation data related to the second observation item which was about and what was discussed about the project with the students, the following situations were observed in the process of meeting with the students and talking about the stages of their projects. Students talked and exchanged their ideas during the day. In the first week, most groups were in the thinking phase. Although some of the students who had the characteristics of being leaders in some groups were willing to make individual decisions, attention was paid to make decisions by group. Students who did not speak much, who were a bit more passive, were encouraged to share their ideas during the interview to make them active. A group working on a drama stated that they wanted to make changes in their stories in the 2nd week and interviews were carried out accordingly. In addition, discussions were held regarding the course and relevance of the project contents. For example, it was decided that the concept of tens and ones was mentioned very little in the content of one of the drama projects. Then the students thought a more appropriate story. In the middle of the third week, all groups decided what they would do and started to implement them. At the end of the $4^{\text {th }}$ week, the projects of the students were completed, and discussions were held on the final arrangements.

The third item in the observation form was about what the students in the group consulted. When analyzing the observation data, it was observed that the students sometimes had difficulty to go further in their studies and asked what to do. Also, it was seen that they explained their projects and asked whether they were suitable or not and whether their parents could help to do their projects or not and asked about what kind of material that could be used in their project. It was observed that some students did not want to be included in the process with the concern of not being able to present a good study. It was tried to prevent this misconception by making necessary interviews with the students.

The fourth item in the interview form was about which ideas were given to students to support them. The observation data related to the fourth item is as follows. In the situations of that students were unable to decide what to do after thinking about 2-3 different ideas, they were given information about what kind of ideas to apply. For example, when a group that was assigned to prepare an educational game project planned a very expensive design, the group was informed that this project required a mastery skill that they were not able to do, and it was going to be costly. Sometimes, when it was observed that there were groups that could not progress in their subjects, options were given about what they could do.

The fifth item in the interview form was about the applicability of the study in the classroom. When looking at the observation data related to the fifth item, it was observed that the implication was a process that was good for students, which allowed them to have a good time, while ensuring that many of them had a better understanding of the subject. However, as mentioned in the first item about the readiness of the students, it was 
observed that the process of understanding the subject and starting to implement it prolonged, and because they had group work for the first time, they had difficulty in implementing the study.

\subsection{The Findings of Semi-Structured Interviews}

The first question in the interview form of the students was, "How did you feel in this process when you were implementing the project?". When the answers to the question were analyzed, it was observed that the students were generally affected positively by the process and they did this by enjoying the work. Some of the students expressed that they were happy with this question, they enjoyed and loved it, and they were not bored. Student 13 in the study stated that:

"I really enjoyed in the project. I like a lot to do these kinds of activities. I wish we can do these kinds of activities all the time."

The Student 5 expressed his opinion related to the project by saying that:

"I am very happy. I had so much fun with my friends. I want to do such activities more and more."

The Student 8 shared her ideas with these sentences:

"Participating in the project with my friends was very beautiful. I felt happy. I had great fun and that made me happy."

When considering the question of "When you work in the group, what kind of contributions do you think you have to the group?" which was the second item in the interview form, in general, it was observed that the students were trying to create a group consciousness. Some of the students suggested that they helped the group with this question, that they offered different ideas, that their friends did not listen to their ideas, that some of them helped their friends in preparing the project and that some of them did not think much about it. The Student 9 stated his thoughts related to the question:

"My friends and I sat down and talked in the break. I thought about the games we played during the nursery school years, and we talked about each other about them. We thought about the theaters there. New theaters (drama) came to our mind."

The Student 7 also mentioned her ideas about the issue: "I thought a story for drama. Fairytales came to my mind and I shared them with my friends. They told me that they liked the idea."

The Student 10 stated her feelings with these statements: "I always thought what to do. When I told my friends what I found, they said no. Then we thought together, we liked, we decided."

When considering the answers to the question of "What benefits did your project have for you to understand and reinforce the subject?" which the third item in the interview form, in general, it was seen that students understood the subject better. Some of the students had a better understanding about the subject, some of them learned it by having fun, some of them did not fully understand it at first and then understood it better. The Student 15 stated that:

"I liked it very much. At first, I understood it, but not exactly. We both enjoyed and learned what my friends did."

The Student 4 shared his thoughts with these sentences: "When you explained the subject, I understood a little, but I did not fully understand. Then I got it better when I watched the shows."

The Student 2 expressed her feelings with these statements:

"This course is so fun, so beautiful. I understood better with these activities. I can do the questions you write on the board now."

When considering the answers to the question of "Have you experienced anything that adversely affected you in this process? Can you tell if you've met?” which was fourth item in the interview form, it was observed that the students did not encounter any problems in the process. It was seen that most of the students did not have a problem with this question, that some of them were sometimes bored, and that some of them had problems with their friends. The Student 5 shared his ideas with these sentences:

"I love to do activities. We always do activities with my mom at home. I had so much fun, so liked it. I didn't have a problem"

The Student 2 stated that:

"My friends never listened to me, they always talked about themselves. They didn't do what I said. I always did what they said.”

Another evidence for some who got bored because of the readiness level was the opinion of the Student 15 . He stated that:

"It was nice, but sometimes I got bored. I didn't think what I wanted. More things came to my friends' mind. I can't think of much."

When analyzing the answers to the question of "What were the benefits of your work in terms of communication with friends?", it was observed that students communicated effectively with their friends in general. Some of the students reported that they were happy to chat with their friends about this question and spent nice time with them, that they had fun in the process, and that they were unable to communicate because they were not active. Related to the project, the Student 6 stated that:

"We were always fighting with (E). But when we were in the same group, we always talked, we love each other from now on.” 
The Student 11 expressed his feelings with these statements:

"We talked and decided together. Our activities were beautiful. From now on, we play together at recess."

The Student 1 also mentioned his own thoughts by saying:

"We loved each other very much. We had fun."

\section{Conclusions and Discussion}

One of the aims of the research is that in addition to the existing course process, students can produce a product by performing group work in a certain process. In addition to the process, they are expected to make sense of tens and ones concepts. Considering these objectives, it was seen that all the 9 groups achieved this aim. In this process, it is observed that student-teacher and student-student collaboration have a very important place. Since the students were in a group work process, in most cases they had to make decisions together. This shows how important the relationship between them is. It was seen that the students shared with each other when they had something to think about or had an idea during the process. In addition, it was observed that the strong teacher-student communication was important for the student to feel confident and to adopt his / her work more. In this respect, the research findings are in harmony with the studies that the teaching through Project method has given positive results on learning ([27], [28], [29]).

It was observed that most of the students were excited and enthusiastic in the process of implementing the project and that the project was arousing curiosity in them. The reason for this is that the students do such an application for the first time. Another reason for this is to convey to the students what this process will bring to them with the power of teacher-student communication. In the same direction, Blumenfeld et al stated that project-based learning is a method for sustaining the motivation [35]. Because the students were not only responsible for themselves, but also, they were responsible for the group they were in, the sense of responsibility and group consciousness were seen to develop during the process. Students saw that beautiful products could be created with cooperation. According to Sezer and Tokcan [30], one of the methods used for the active participation of the students in the class is collaborative learning. Cooperative learning also contributes to the academic success of the students. In this respect, the findings of these two studies are similar.

In addition to the normal course process, the implication of Project studies shows that students learn by having fun, that they listen to the lesson and that they enjoy the lesson without being bored. Each group has carried out a separate study in the form of educational games, educational materials and educational dramas. For example, it was observed that both the visual and auditory intelligence of the students were brought to the fore by performing drama studies, and that the students actively learned by participating in the course process. According to Ozsoy and Yuksek [31], learning through experience provides the permanence of the information the student has learned, and creative drama helps the student express himself, develop his creativity and make learning more permanent. In this respect, it is observed that these two studies have similar findings.

Project studies are thought to have a positive impact on the normal course process. Although students have an idea about the subject in a normal way, the project studies create an environment in which the students are active and help them make sense of the subject. Korkmaz and Kaptan [10] also believe that the project work is not a contribution to primary education but is considered as complementary to all subjects in the curriculum.

Considering that everyone has different intelligence and different interests, it can be said that this study facilitates students' learning. Because the students with different types of intelligence and interest are seen to understand the subject better with educational drama, educational material and educational games studies by watching different studies of their interests. According to Saracoglu, Akamca and Yesildere [15], the projects allow the implication of alternative approaches to individual differences, intelligence, learning styles, skills or inadequacies of the students. Uluyol and Karadeniz [14] think that teachers should know the level of understanding of individuals and what they learn at the end of the project in the process of project-based teaching. They also think that standard testing should not be appropriate for the project-based learning process because of focusing on low level understanding, instead of it, alternative assessment methods such as evaluating student products and evaluating interviews should be used during the project process. Since a similar evaluation process is carried out in this study, two studies are consistent with each other.

Radhwan [32] states that in collaborative learning with group work, students must work with each other in a cooperative way so that students can find many opportunities to interact with each other in the process. According to Turkmen [33], group work that includes an age appropriate activity and attracts the interest of the student, increases the interest of the student on the subject studied and makes the study more efficient. In this study, it was seen that most of the students did not have any communication difficulties, however, some students did not listen to their friends and they could not establish healthy communication. This kind of students is thought to have experience at least with the group study for the first time and have an idea of how to work in collaboration. In this respect, these findings are consistent with the findings of Radhwan [32] and Turkmen [33]. 


\section{REFERENCES}

[1] TDK (Türk Dil Kurumu), (2018). http://www.tdk.gov.tr

[2] Aydın, B. (2003). Bilgi Toplumu Oluşumunda Bireylerin Yetiştirilmesi ve Matematik Öğretimi. Pamukkale Üniversitesi Eğitim Fakültesi Dergisi, 2(14), 183-190.

[3] Akay, H. (2006). Problem Kurma Yaklaşımı ile Yapılan Matematik Öğretiminin Öğrencilerin Akademik Başarısı, Problem Çözme Becerisi ve Yaratıcılığı Üzerindeki Etkisinin İncelenmesi. Doktora Tezi, Gazi Üniversitesi, Ankara.

[4] Kutluca, T., \& Zengin, Y. (2011). Matematik Öğretiminde Geogebra Kullanımı Hakkında Öğrenci Görüşlerinin Değerlendirilmesi. Dicle Üniversitesi Ziya Gökalp Eğitim Fakültesi Dergisi, Sayı 17, 160-172.

[5] MEB Talim ve Terbiye Kurulu Başkanlığı, (2015). İlkokul Matematik Dersi (1, 2, 3 ve 4. Sinıflar) Öğretim Programı, Ankara.

[6] Köroğlu, H., \& Yeşildere, S. (2004). İlköğretim Yedinci Sınıf Matematik Dersi Tamsayılar Ünitesinde Çoklu Zekâ Teorisi Tabanlı Öğretimin Öğrenci Başarısına Etkisi. Gazi Eğitim Fakültesi Dergisi, 24(2), 25-41.

[7] Çakmak, M. (2004). İlköğretimde matematik öğretimi ve öğretmenin rolü (Elektronik versiyon), Matematikçiler Derneği, http://www.matder.org.tr (Downloaded on 14.12.2018).

[8] Yaşar, Ş., \& Papatğa, E. (2015). İlkokul Matematik Derslerine Yönelik Yapılan Lisansüstü Tezlerin İncelenmesi. Trakya Üniversitesi Eğitim Fakültesi Dergisi, 5(2), 113-124.

[9] MEB. (2005). İlköğretim Matematik Dersi Öğretim Programı ve Kılavuzu. MEB Yayınları: Ankara.

[10] Korkmaz, H., \& Kaptan, F. (2002). Fen Öğretiminde Proje Temelli Öğrenme Yaklaşımının İlköğretim Öğrencilerinin Akademik Başarı, Akademik Benlik Kavramı ve Çalışma Sürelerine Etkisi, Hacettepe Üniversitesi Eğitim Fakültesi Dergisi, 22, 91-97.

[11] Develi, M., \& Orbay, K. (2003). İlköğretimde Niçin ve Nasıl Bir Geometri Öğretimi. Milli Eğitim Dergisi, No:157.

[12] Erdem, M., \& Akkoyunlu, B. (2002). İlköğretim Sosyal Bilgiler Dersi Kapsamında Beşinci Sınıf Öğrencileriyle Yürütülen Ekiple Proje Tabanlı Öğrenme Üzzerine Bir Çalışma. İlkögrretim-Online (1), 2-11.

[13] Güven, İ. (2013). Fen ve Teknoloji Öğretmen Adaylarının Proje Yönetimi Deneyimlerinin Değerlendirilmesi. Hacettepe Üniversitesi Eğitim Fakültesi Dergisi, Özel Say1(1), 204-218.

[14] Uluyol, Ç., \& Karadeniz, Ş. (2009). Bir Harmanlanmış Öğrenme Ortamı Örneği: Öğrenci Başarısı ve Görüşleri. Yüzüncü Yıl Üniversitesi Eğitim Fakültesi Dergisi, 6(1), 60-84.

[15] Saracoğlu, A. S., \& Akamca, G. Ö., \& Yeşildere S. (2006). İlköğretimde Proje Tabanlı Öğrenmenin Yeri. Türk Eğitim Bilimleri Dergisi, 4(3), 241-260.
[16] Korkmaz, H., \& Kaptan, F. (2001). Fen Eğitiminde Proje Tabanlı Öğretim Yaklaşımı. Hacettepe Üniversitesi Eğitim Fakültesi Dergisi, Say1 20, 193-200.

[17] Cengizhan, S. (2007). Proje Temelli ve Bilgisayar Destekli Öğretim Tasarımlarının; Bağımlı, Bağımsız ve İş Birlikli Öğrenme Stillerine Sahip Öğrencilerin Akademik Başarılarına ve Kalıcılığına Etkisi. Türk Eğitim Bilimleri Dergisi, 5(3), 377-401.

[18] Gelişgen, M. (2007). Mesleki ve Teknik Orta öğretimde Proje Temelli Öğretim Programlarının Geliştirilmesi. Yüksek Lisans Tezi, Afyon Kocatepe Üniversitesi, Afyon.

[19] Angın, D. (2013). Proje temelli eğitim programının 60-71 aylık çocukların kavram gelişimine etkisi. Doktora Tezi, Selçuk Üniversitesi, Konya.

[20] Obalı, H. (2009). Okul Öncesi Eğitimi Almakta Olan Altı Yaş Grubu Çocuklarına Verilen Proje Yaklaşımıyla Beslenme Eğitiminin Beslenme Bilgi Düzeyine Etkisi. Yüksek Lisans Tezi, Selçuk Üniversitesi, Konya.

[21] Çevik, M. (2016). Fen Bilimleri Dersinde Proje Tabanlı Öğrenme Yaklaşımının İlkokulda Öğrenim Görmekte Olan Hafif Düzeyde Zihinsel Engele Sahip Öğrencilerin Akademik Başarılarına ve Tutumlarına Etkisi. Education Sciences, 11(1), 36-48.

[22] Karaçallı, S. (2011). İlköğretim 4. Sınıf fen ve teknolojik dersinde proje tabanlı öğrenme yönteminin akademik bașarıya, tutuma ve kalıcılığa etkisi. Yüksek Lisans Tezi, Mehmet Akif Ersoy Üniversitesi, Burdur.

[23] Gündüz, M., \& Özerbaş, A. (2014). Sorumluluk Değerinin Proje Tabanlı Öğrenmeyle Öğretiminin İlköğretim 3. Sınıf Öğrencilerinin Tutumlarına Etkisi. Uluslararası Sosyal Araştırmalar Dergisi, 7(32), 520-532.

[24] Tunç, A. \& Tuzcuoğlu, N. (2014). Aile Katılımlı Proje Tabanlı Öğrenme Yaklaşımının 60-72 Aylık Çocukların Farklı Kültürlere Bakıș Açısına Etkisinin İncelenmesi. Akademik Sosyal Araştırmalar Dergisi, 2(7), 510-52.

[25] Yin, R.K (1984) Case Study Research: Design and Methods. Sage Publications, Beverly Hills, California.

[26] MEB. (2018). Matematik Dersi Öğretim Programı (İlkokul ve Ortaokul 1, 2, 3, 4, 5, 6, 7 ve 8. siniflar), Ankara.

[27] Kalaycı, N. (2008). Yükseköğretimde Proje Tabanlı Öğrenmeye İlişkin Bir Uygulama. Eğitim ve Bilim Dergisi, 33(147), 85-105.

[28] Nikbay, N. A. (2009). Anlatma Yöntemi ile Proje Tabanlı Öğrenme Yönteminin Öğrenci Başarısı Açısından Verimliliğinin Karşılaştırılması. Yüksek Lisans Tezi, Gazi Üniversitesi, Ankara.

[29] Çakan, S. (2005). Proje Tabanlı öğrenme Yaklaşımının Uygulandığ 16 . Sınıf Matematik Dersine İlişkin Öğrenci ve Öğretmen Görüşleri. Yüksek Lisans Tezi, Balıkesir Üniversitesi, Balıkesir.

[30] Sezer, A., \& Tokcan, H. (2003). İş Birliğine Dayalı Öğrenmenin Coğrafya Dersinde Akademik Başarı Üzerine Etkisi. Gazi Ĕ̆itim Fakültesi Dergisi, 23(3), 227-242.

[31] Özsoy, N., \& Yüksel, S. (2007). Matematik Öğretiminde Drama. Dokuz Eylül Üniversitesi Buca Eğitim Fakültesi Dergisi, Say1 21, 32-36. 
[32] Radhwan, H. (2013). Discourse Analysis in Groupwork Interaction in a task-based and cooperative classroom. Yüksek Lisans Tezi, Ufuk Üniversitesi, Ankara.

[33] Türkmen, A. (1997). İlköğretim Okullarında Gökyüzü ve Dünyamız Ünitesinin Ödül ve Grup Çalışması Metoduyla İşlenmesinin Fen Öğretimine Etkisi. Yüksek Lisans Tezi, Marmara Üniversitesi, İstanbul.

[34] Bell, S. (2010). Project-Based Learning for the 21st Century: Skills for the Future, The Clearing House, 83:2, 39-43, DOI: 10.1080/00098650903505415

[35] Blumenfeld, P. C., Soloway, E., Marx, R. W., Krajcik, J. S., Guzdial, M. \& Palincsar, A. (2011). Motivating Project-Based Learning: Sustaining the Doing, Supporting the Learning, Educational Psychologist, 26(3-4), 369-398.

[36] Eskrootchi, R., \& Oskrochi, G. R. (2010). A Study of the Efficacy of Project-based Learning Integrated with Computer-based Simulation- STELLA. Educational Technology \& Society, 13 (1), 236-245. 